\title{
Kemenarikan dalam Pemberdayaan Masyarakat di Kampung Wisata Cibunut Kota Bandung
}

\author{
(Attractiveness in Community Empowerment \\ in Cibunut Tourism Village, Bandung City)
}

\author{
Anti Riyanti ${ }^{1}$, Lia Afriza ${ }^{2}$ \\ 1,2Sekolah Tinggi Ilmu Ekonomi Pariwisata Yapari \\ anti.ryantik@gmail.com
}

\begin{tabular}{l} 
Info Artikel \\
\hline Diterima Agustus 1, 2020 \\
Direvisi Agustus 20, 2020 \\
Dipubikasi September 20, \\
2020
\end{tabular}

\section{Kata Kunci:}

Kemenarikan; Kampung

Wisata; Pemberdayaan

Masayrakat

Keywords :

Attracticeness; People

Empowerment; Tourist

Village

\begin{abstract}
Abstrak
Kota Bandung memiliki berbagai macam destinasi wisata yang menarik minat wisatawan lokal maupun mancanegara. Berbagai macam instansi yang terkait dengan pariwisata perlu memperhatikan perkembangan destinasi wisata di Kota Bandung karena memiliki banyak pilihan, salah satunya wisata buatan yang menarik yaitu Kampung Wisata Cibunut Kelurahan Kebon Pisang Kecamatan Sumur Bandung. Dalam penelitian ini metode kualitatif digunakan dengan teknik pengumpulan data yang berbentuk kalimat dan gambar. Hasil dari penelitian ini bahwa existing di Kampung Wisata Cibunut sudah baik fasilitas wisatanya, dengan mendapatkan nilai 109,4 dan belanja pariwisata di posisi 110. Pada faktor kemenarikan juga sudah baik, atraksi mendapat nilai rata-rata 116,6 . Aksesibilitas 118,5 dan ancillary 114,2. Hal ini menyatakan bahwa keseluruhan Kampung Wisata Cibunut sudah baik, namun harus dikembangkan dalam paket wisata khusus di Kampung Wisata Cibunut.
\end{abstract}


Accessibility is 118.5 and Ancillaryis 114.2. It is stated that the whole Kampung Wisata Cibunut is good, but need to be developed in a special tour package in Kampung Wisata Cibunut.

\section{PENDAHULUAN}

Daya guna pariwisata dengan optimal mampu tingkatkan pertumbuhan ekonomi, hal tersebut yang menjadi pertimbangan dalam penanganan upaya pengembangan destinasi wisata di Indonesia. Pelaku pariwisata melakukan pengembangan melalui penelitian, observasi terhadap destinasi wisata di Indonesia. Langkah tersebut bertujuan untuk mengetahui potensi dan permasalahan pada setiap destinasi yang kemudian mencari solusi.

Kepariwisataan sebagai bagian integral dari pembangunan nasional yang sistematis, terencana, terpadu, berkelanjutan, dan bertanggung jawab dengan tetap memperhatikan perlindungan nilai-nilai agama, budaya dalam masyarakat, kelestarian serta mutu lingkungan hidup untuk kepentingan nasional. Kegiatan perekonomian dalam sektor pariwisata menjadi prioritas bagi Indonesia yang memiliki potensi wilayah dengan daya tarik wisatanya, budaya dan kehidupan masyarakat. Lebih lanjut, (Risman et al., 2016) menyatakan bahwa sector pariwisata mampu mengentaskan kemiskinan di daerah karena 4 (empat) karakteristik yang dimilikinya yaitu kemungkinan memasarkan produk local dengan adanya wisatawan yang datang berkunjung, membuka peluang diversifikasi ekonomi lokal yang dapat meyentuh kawasan marginal, peluang bagi ekonomi padat karya skala kecil dan menengah yang terjangkau kaum miskin, serta tidak bergantung modal finansial semata akan tetapi lebih mengedepankan modal budaya dan modal alam yang dimiliki berbagai daerah di Indonesia. Sehingga tidak mengherankan apabila sektor kepariwisataan dianggap sangat menjanjikan dan telah menjadi salah satu sumber andalan devisa bagi keuangan negara, yaitu di peringkat ke dua pada 2019 setelah kelapa sawit (Ocktaviany, 2019). Untuk meningkatkan pariwisata, terkait antara produk berupa daya tarik wisata yang dapat dijual dengan sarana dan prasarana pendukung industri pariwisata. 
Usaha pengembangan daerah tujuan wisata harus memperhatikan faktor yang mempengaruhi keberadaan suatu daerah tujuan wisata. Dewi (2013) berpendapat bahwa peran pemerintah dalam pengambangan desa wisata harus dibatasi dan partisipasi masyarakat sebagai pelaku utama di desa wisata harus didorong agar mereka mampu mempergunakan semua sumberdaya local yang tersedia di daerahnya untuk memberdayakan dan memakmurkan dirinya. Destinasi wisata yang ada di Indonesia merupakan kekayaan alam dengan keunikannya masing-masing. Setiap daerah di Indonesia memiliki keindahan alam maupun adat istiadat (budaya) serta hasil karya masyarakat yang ada di daerah tersebut sehingga menarik wisatawan untuk berkunjung.

Pengetahuan daya tarik wisata harus dimiliki pengusaha di bidang pariwisata dan juga untuk para generasi muda sebagai warisan pengelola pariwisata Indonesia di masa depan karena menurut Fitriana dan Sarmadi (2019) daya tarik suatu destinasi wisata memiliki pengaruh terhadap kepuasan wisatawan yang pada gilirannya akan berpengaruh pula pada tingkat kunjungan wisatawan di destinasi tersebut. Hal ini menjadikan daya tarik sebagai faktor penting dalam pengembangan dan pegelolaan sebuah destinasi.

Kota/Kabupaten Bandung juga memiliki berbagai macam destinasi wisata yang menarik minat wisatawan lokal maupun mancanegara. Berbagai macam instansi yang terkait dengan pariwisata perlu memperhatikan perkembangan destinasi wisata di Kota Bandung karena memiliki banyak pilihan untuk berwisata terutama berwisata sejarah dan wisata buatan yang menarik, salah satunya yaitu Kampung Wisata Cibunut.

Berdasarkan hasil observasi di atas, penulis mendapatkan data kunjungan wisatawan yang datang ke Kampung Wisata Cibunut sebanyak lebih dari 900 yang diambil melalui rekapitulasi data kunjungan wisatawan untuk tahun 2019. Dari 900 wisatawan yang datang ke Kampung Wisata Cibunut seluruh pengunjung termasuk kategori wisatawan nusantara. Dilihat dari data maka motivasi pengunjung sangat sedikit untuk berkunjung ke Kampung Wisata Cibunut. Sehingga rumusan penelitian ini adalah:

1. Bagaimana kondisi existing Kampung Wisata Cibunut Kota Bandung.

2. Bagaimana faktor-faktor kemenarikan dalam pemberdayaan masyarakat di Kampung Wisata Cibunut Kota Bandung. 
Pariwisata Menurut UU No. 10 Tahun 2009, "Pariwisata ialah berbagai macam kegiatan wisata dan didukung berbagai fasilitas serta layanan yang disediakan oleh masyarakat, pengusaha, pemerintah dan pemerintah daerah." Menurut World Tourism Organization (WTO), "Pariwisata merupakan suatu kegiatan manusia yang melakukan perjalanan ke dan tinggal di daerah tujuan di luar lingkungan kesehariannya." Sedarmayanti dkk. (2018) berpendapat bahwa,

"Pariwisata adalah perjalanan yang dilakukan sementara waktu, yang diselenggarakan dari suatu tempat ke tempat lain, dengan maksud bukan untuk berusaha atau mencari nafkah di tempat yang dikunjungi, tetapi untuk menikmati perjalanan tersebut guna pertamasyaan dan rekreasi atau memenuhi keinginan yang beraneka ragam."

Daya Tarik Wisata Berdasarkan Undang-Undang Republik Indonesia No. 10 Tahun 2009, "Daya Tarik Wisata dijelaskan sebagai segala sesuatu yang memiliki keunikan, kemudahan, dan nilai yang berupa keanekaragaman kekayaan alam, budaya, dan hasil buatan manusia yang menjadi sasaran atau kunjungan wisatawan." Marpaung (2002:78), memberikan definisi mengenai daya tarik ialah "Suatu bentukan atau fasilitas dan aktifitas yang berhubungan, yang dapat menarik wisatawan atau pengunjung untuk datang ke suatu daerah atau tempat tertentu." Daya tarik wisata yang juga disebut "Objek wisata merupakan potensi yang menjadi pendorong kehadiran wisatawan ke suatu daerah tujuan wisata." (Suwantoro, 2004:19)

Dalam dunia pariwisata kemenarikan suatu daya tarik wisata merupakan produk wisata yang sangat mendasar dan penting untuk mendorong seseorang mengunjungi daya tarik wisata tersebut. Daya tarik wisata yang ada merupakan acuan untuk melihat kekuatan terhadap tujuan yang akan dicapai. Vengesayi dkk (2009) bependapat bahwa selama sebuah destinasi dianggap popular, maka wisatawan akan tertarik mengunjunginya, namun tidak dapat dipungkiri bahwa daya tarik sebuah destinasi wisata akan meningkat sesuai dengan ketersediaan dukungan pelayanan dan sikap penduduk lokal. Hal ini menunjukkan bahwa daya tarik yang dibarengi dengan pengelolaan yang baik dan kesiapan masyarakat untuk menerima wisatawan merupakan factor-faktor yang menentukan kemampuan sebuah destinasi wisata dalam menarik wisatawan. 
Penentuan factor-faktor daya tarik wisata dengan kriteria menurut Suwantoro (2004:19)“meliputi objek yang menarik, penyediaan fasilitas yang memenuhi, adanya jalur penghubung yang menunjang. Kesemuanya tercermin pada penyediaan prasarana dan sarana pariwisata serta citra wisatawan sehingga didapatkan 4 faktor kemenarikan, yaitu:

1. Tingkat keanekaragaman aktivitas wisata (Atraksi), melihat jumlah kegiatan wisata yang ada, meliputi; atraksi alam (flora dan fauna, pemandangan alam, fasilitas olahraga dan memancing).

2. Tingkat kelengkapan fasilitas pelayanan wisata (Amenitas), meliputi jumlah kelengkapan fasilitas, yaitu penginapan, tempat makan, toko cinderamata dan fasilitas umum.

3. Tingkat kemudahan pencapaian (Aksesibilitas), dengan mengukur fungsi/status jalur transportasi, kondisi prasarana perhubungan dan prasarana angkutan umum lainnya, meliputi; jaringan dan moda angkutan, jarak dari kota terdekat, frekuensi dan tarif, masalah polusi, kapasitas jalan, kualitas jalan, lampu penerangan jalan dan papan petunjuk lokasi.

4. Tingkat pengelolaan potensi wisata (Ancillary), melihat ada atau tidaknya pengelolaan potensi wisata, meliputi:

a. Perlindungan terhadap sumber daya alam dan lingkungan.

b. Keberlanjutan ekonomi.

c. Peningkatan integritas budaya.

d. Nilai pendidikan dan pembelajaran."

Pemberdayaan masyarakat menurut Hadiwijoyo (2012:28), "Pemberdayaan masyarakat adalah suatu proses yang berjalan terus menerus dalam meningkatkan kemampuan dan kemandirian masyarakat serta meningkatkan taraf hidupnya". Dalam hal ini potensi masyarakat ditingkatkan untuk mencapai kualitas hidup dalam kegiatankegiatan masyarakat. 


\section{Kampung Wisata Cibunut}

1. Tingkat keanekaragaman aktivitas wisata (Atraksi);
2. Tingkat kelengkapan aktivitas wisata (Amenitas);
3. Tingkat kemudahan pencapaian (Aksesibilitas);
4. Tingkat pengelolaan potensi wisata (Ancillary);

Kemenarikan Dalam Pemberdayaan Masyarakat Di Kampung Wisata Cibunut Kota Bandung

\section{Sumber: Olahan Penulis (2020)}

\section{METODE PENELITIAN}

Dalam penelitian, penulis memerlukan adanya suatu pendekatan sebagai dasar dalam melaksanakan penelitian mengenai faktor-faktor kemenarikan di Kampung Wisata Cibunut dalam upaya meningkatkan kunjungan wisatawan. Metode yang digunakan adalah metode kualitatif. Menurut Sugiyono (2011:23), “Data kualitatif adalah data yang berbentuk kalimat, kata atau gambar. Sedangkan data kuantitatif adalah data yang berbentuk angka atau data kualitatif yang digunakan (scoring)."

\section{Operasional Variabel Penelitian}

Sesuai dengan desain penelitian ini yakni deskriptif dimana penelitian ini mengenai faktor-faktor kemenarikan Kampung Wisata Cibunut, dengan menggunakan 1 variabel dengan 4 sub variabel, untuk mengukur variabel penelitian maka variabel dan masingmasing sub variabel dioperasionalisasikan lebih spesifik sebagaimana diuraikan pada tabel berikut ini: 
Tabel Operasional Variabel Penelitian

\begin{tabular}{|c|c|c|}
\hline Variabel & $\begin{array}{c}\text { Sub } \\
\text { Variabel }\end{array}$ & Indikator \\
\hline \multirow{15}{*}{$\begin{array}{l}\text { Suwantoro } \\
\text { (2004:19), "Penentuan } \\
\text { faktor-faktor daya tarik } \\
\text { wisata dengan kriteria, } \\
\text { meliputi objek, } \\
\text { penyediaan fasilitas dan } \\
\text { adanya jalur penghubung } \\
\text { yang menunjang untuk } \\
\text { memberikan kesan yang } \\
\text { baik kepada wisatawan." }\end{array}$} & \multirow[t]{4}{*}{ Atraksi } & 1. Pemandangan Alam \\
\hline & & $\begin{array}{l}\text { 2. Keanekaragaman flora dan } \\
\text { fauna }\end{array}$ \\
\hline & & 3. Keadaan Iklim \\
\hline & & 4. Kemenarikan aktivitas wisata \\
\hline & \multirow[t]{6}{*}{ Amenitas } & 5. Kondisi lahan parker \\
\hline & & 6. Kondisi toilet \\
\hline & & 7. Sarana informasi wisata \\
\hline & & 8. Toko cinderamata \\
\hline & & 9. Kondisi kendaraan wara-wiri \\
\hline & & 10. Kondisi restoran/kantin \\
\hline & Aksesibilitas & 11. Kondisi akses menuju lokasi \\
\hline & & $\begin{array}{l}\text { 12. Kemudahan akses informasi } \\
\text { menuju lokasi }\end{array}$ \\
\hline & \multirow[t]{3}{*}{$\begin{array}{l}\text { Ancilarry } \\
\text { Service }\end{array}$} & $\begin{array}{l}\text { 13. Kelestarian alam } \\
\text { lingkungan }\end{array}$ \\
\hline & & $\begin{array}{l}\text { 14. Sumber informasi } \\
\text { disajikan manajemen }\end{array}$ \\
\hline & & $\begin{array}{l}\text { 15. Kualitas pelayanan } \\
\text { diberikan manajemen }\end{array}$ \\
\hline
\end{tabular}

Sumber: Olahan Peneliti, 2020

\section{Jenis Sumber Data Penelitian}

Berdasarkan pengumpulan data menggunakan sumber primer dan sekunder. Sumber data primer adalah sumber yang langsung memberikan data kepada pengumpul data. Sumber data primer diperoleh penulis, melalui wisatawan yang berkunjung ke Kampung Wisata Cibunut serta pengelola Kampung Wisata Cibunut.

Wardiyanta (2006:28),’Data primer adalah informasi yang diperoleh dari sumbersumber primer, yakni yang asli, informasi dari tangan narasumber atau responden.” Jadi 
data primer adalah data yang diperoleh dengan peninjauan langsung ke lapangan melalui penyebaran kuesioner, observasi, dan wawancara.

Sumber data sekunder adalah sumber yang tidak langsung memberikan data kepada pengumpul data. Sumber data sekunder didapat dari semua informasi mengenai Kampung Wisata Cibunut. "Data sekunder adalah informasi yang diperoleh secara tidak langsung dari responden, tetapi dari pihak ketiga" (Wardiyanta, 2006:28). Jadi data sekunder adalah data yang diperoleh dari sejarah atau literatur, buku-buku, juga dari artikel atau tulisan ilmiah yang berhubungan dengan topik permasalahan yang diteliti.

\section{Teknik Pengumpulan}

Teknik pengumpulan data dimaksudkan untuk pencatatan peristiwa atau karakteristik dari sebagian atau seluruh elemen atau unsur populasi penelitian. Teknik pengumpulan data yang digunakan untuk mendukung penelitian ini dilakukan dengan 2 teknik yaitu pengumpulan data primer dan data sekunder. Data primer diambil dengan cara wawancara dan kuesioner sedangkan data sekunder diambil dengan cara studi kepustakaan dan studi dokumentasi.

1. Wawancara yaitu salah satu teknik pengumpulan data yang dilakukan berhadapan secara langsung dengan cara mengadakan tanya jawab beberapa sumber data. Dalam penelitian ini wawancara dilakukan kepada beberapa narasumber, yaitu pengelola Kampung Wisata Cibunut serta wisatawan yang berkunjung ke tempat tersebut.

2. Kuisioner adalah salah satu teknik pengumpulan data dalam bentuk tertulis melalui sebuah daftar pertanyaan yang disiapkan sebelumnya dan harus diisi oleh reponden. Responden adalah wisatawan yang berkunjung ke lokasi sebagai alat untuk mengukur tingkat kemenarikan daya tarik penelitian.

3. Studi Dokumentasi merupakan suatu teknik pengumpulan data yang dilakukan dengan mengambil foto kemudian mengarsipkan daya tarik penelitian. Dalam penelitian ini studi dokumentasi dilakukan dengan cara pendokumentasian Kampung Wisata Cibunut.

\section{Teknik Pengolahan Data}


Teknik yang digunakan penulis untuk data yang diperoleh dari hasil penelitian, kemudian diolah secara statistik. Teknik pengukuran dengan cara membuat skala yang digunakan dalam penelitian ini yaitu skala likert. Menurut Sugiyono (2007:86), "Skala likert digunakan untuk mengukur sikap, pendapat dan persepsi seseorang atau sekelompok orang tentang fenomena sosial. Dalam penelitian ini, fenomena sosial telah diterapkan secara spesifik oleh peneliti, yang selanjutnya disebut sebagai variabel penelitian. Dalam skala likert maka variabel akan diukur dan dijabarkan menjadi indikator variabel. Kemudian indikatorindikator tersebut dijadikan sebagai titik tolak untuk menyusun item-item instrumen yang dapat berupa pertanyaan-pertanyaan."

Skala ini dikembangkan oleh Rensis Likert, teknik ini juga bisa disebut sebagai Summarated Rating Method, pada umumnya responden harus memilih lima alternatif jawaban, yaitu; sangat baik, baik, cukup, kurang baik, sangat kurang baik. Sehingga jumlah skor yang didapatkan berasal dari hasil nilai periem dikali dengan responden. Responden yang digunakan dalam penelitian ini sebanyak 100 responden. Penilaian akhir akan didapatkan dan diketahui untuk setiap pertanyaan yang diajukan dengan garis kontinum interval sebagai berikut:

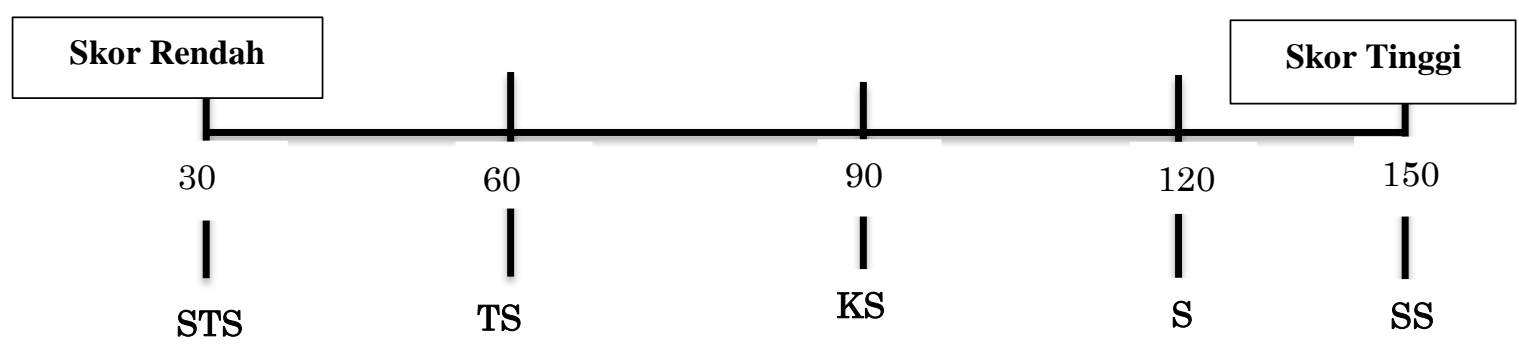

\section{HASIL DAN PEMBAHASAN}

\section{Kondisi existing Kampung Wisata Cibunut Kota Bandung}

a) Lokasi Penelitian

Lokasi yang menjadi objek penelitian adalah Kampung Wisata Cibunut, Jalan Sunda Gang Cibunut, Kelurahan Kebon Pisang, Kecamatan Sumur Bandung, Kota Bandung.

b) Profil Kampung Wisata Cibunut 
Cibunut merupakan sebuah kampung yang berada di Kelurahan Kebon Pisang, Kecamatan Sumur Bandung, Kota Bandung. Dikenal sebagai wilayah yang kumuh dan padat penduduk. Namun, kini Kampung Cibunut telah berubah menjadi kampung kreatif yang ramah lingkungan. Saat ini Kampung Cibunut merupakan kawasan yang menjadi salah satu titik pantau penilaian untuk ADIPURA dan menjadi percontohan pengelolaan perumahan berwawasan lingkungan atau dikenal dengan istilah KBS (Kawasan Bebas Sampah). Oleh karena itu, Gerakan Indonesia Diet Kantong Plastik melakukan riset dan edukasi kepada masyarakat Kampung Cibunut sebagai upaya untuk mendidik warga setempat agar mengurangi kantong plastik dan mulai membawa tas belanja sendiri serta menjadikan Kampung Cibunut wilayah percontohan kampung bebas plastik.

Tujuan Kampung Wisata Cibunut mengurangi kantong plastik agar masyarakat sekitar membiasakan mengurangi limbah plastik. Sampah yang terangkut ke TPS berkurang. Sehingga patisipasi masyarakat tentang pengolahan sampah pun menjadi meningkat.

Selain pengolahan sampah, Kampung Wisata Cibunut ini mempunyai ciri khas dari kampung lain yaitu adanya 5 zonasi mural yang berada di 9 RT, membuat keunikan di kampung ini. Zonasi tersebut yaitu:

1) Zona "Perdamaian" di RT 7 dan RT 9. Pada zona ini, seniman membuat desain yang menceritakan tentang perdamaian.

2) Zona "Word Insight" yang bertema pengetahuan. Pada zona ini, desain yang menggambarkan informasi mengenai pengetahuan secara umum seperti peta dunia, infografis tentang pelajaran sains. Zona dengan mural bertema pengetahuan ini dapat ditemui di RT 4.

3) Zona "local genius" di RT 8 dan RT 3. Dalam zona ini, Bandung adalah salah satu sumber inspirasinya.

4) Zona "environment” di RT 6 dan RT 5. Isu lingkungan merupakan induk tema pada zona ini. Seniman mural mendesain gambar tentang zero waste, pemilahan sampah, 3R (reduce, reuse, recycle) dan lainlain. Berhubung penduduk di zona ini banyak 


\section{JURNAL

memiliki anak kecil, mural dituangkan dalam bentuk-bentuk permainan seperti ular tangga, mencari perbedaan dan teka teki silang.

5) Zona "local culture" di RT 1 dan RT 2 yang mengangkat isu kearifan ranah budaya Indonesia mulai dari Sabang sampai Merauke. Di zona ini, mural yang dibuat memiliki kekuatan komunikasi yang diharapkan dapat membangun rasa cinta terhadap kearifan kebudayaan lokal.

\section{c) Demografi}

RW 07 Kelurahan Kebon Pisang, Kecamatan Sumur Bandung, kampung seluas $31.478 \mathrm{~m}^{2}$ ini berada di antara dua jalan yakni Jalan Veteran dan Jalan Baranangsiang. Batas wilayah selatan dan timur Kampung Wisata Cibunut adalah aliran Sungai Cibunut. Jumlah penduduk RW 07 melingkupi 9 RT sebanyak 1675 orang dengan jumlah KK 511 orang.

Salah satu dinding rumah warga RT 5 Kampung Wisata Cibunut tertera kalimat "The Power of Collaboration" yang berarti kalimat itu menunjukkan kekuatan kolaborasi warga kampung yang langsung mewarnai dinding-dinding rumah. Satu hal yang membedakan Kampung Wisata Cibunut dengan kampung-kampung serupa di daerah lain. Ada sembilan warna yang dipakai untuk menandai rumah warga, sembilan warna itu menjadi ciri khas untuk sembilan RT. Melalui warna, diharapkan tidak ada lagi pengunjung yang tersesat atau kebingungan mencari alamat. Peta besar kampung tertempel di dinding sekretariat Karang Taruna yang terletak di gang utama Kampung Wisata Cibunut.

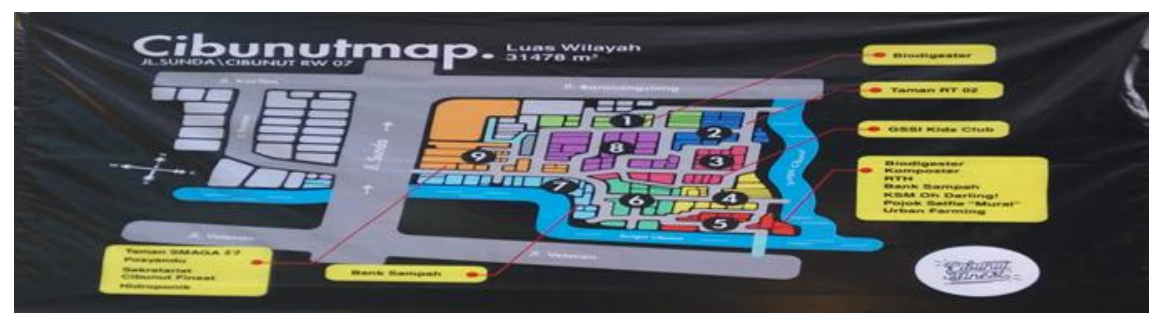

Gambar Peta Kampung Wisata Cibunut Bandung Sumber: Dokumen penulis, 2019

d) Karakteristik Wisatawan 
Secara geografis, karakteristik wisatawan yang berkunjung ke Kampung Wisata Cibunut didominasi oleh wisatawan luar Kota Bandung (63\%). Sementara berdasarkan sosio-demografis, karakteristik wisatawan yang berkunjung sekitar 21-30 tahun (64\%), wisatawan yang memiliki tingkat pendidikan perguruan tinggi (60\%), wisatawan yang berstatus mahasiswa (50\%), wisatawan yang berpenghasilan $<$ Rp. 500.000,- (63\%) dan memilih berkunjung bersama teman (53\%). Secara psikografis, wisatawan yang datang berkunjung bertujuan untuk penelitian (30\%) dan menghabiskan waktu untuk cara pengolahan sampah.

e.) Aktivitas pemberdayaan masyarakat Kampung Wisata Cibunut

Pada umumnya hampir $70 \%$ masyarakat terlibat dalam kegiatan pariwisata dengan score 110 berarti berada di tingkatan baik. Aktivitas yang melibatkan masyarakat dari mulai penggiat lingkungan (penghijauan halaman, pengumpulan limbah, pengolahan limbah), UMKM (pengolahan tahu dan daur ulang sampah), penyediaan makanan dan minuman, pengelola kampung wisata dan pemandu wisata, semuanya dilakukan oleh masyarakat Kampung Cibunut. Pemberdayaan masyarakat lokal menjadi penting karena menurut Wearing (2002) berhasil tidaknya pengembangan suatu desa wisata sangat tergantung pada tingkat penerimaan dan dukungan masyarakat lokal. Hal senada diungkapkan oleh Trisnawati dkk (2018) yang berpendapat bahwa pemberdayaan akan terus memacu masyarakat untuk inovatif dan kreatif dalam mengolah sumber daya yang dimilikinya. . Ada 6 aktivitas yang sudah dilakukan di Kampung Wisata Cibunut yaitu:

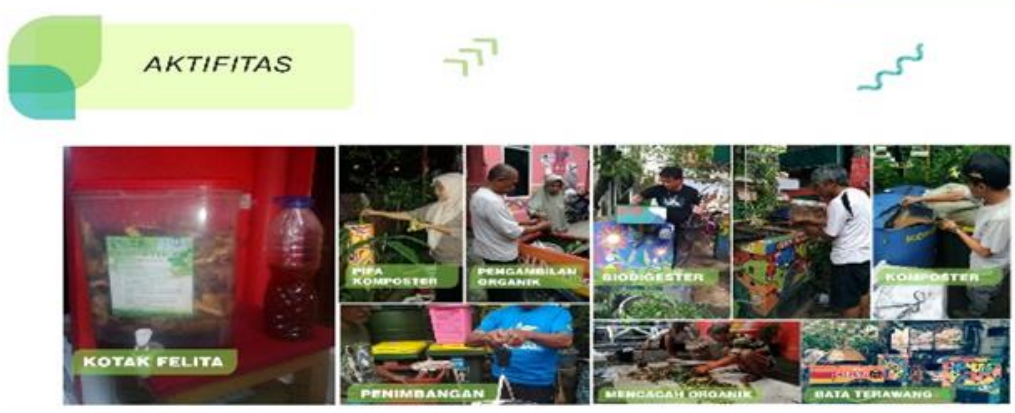

\section{Gambar Aktivitas Kampung Wisata Cibunut Bandung}




\section{Sumber: Dokumen penulis, 2019}

\section{1.) Kebersihan dan Pengolahan Sampah}

Aktivitas rutin yang dilakukan oleh pengurus inti yang berjumlah 12 orang dan dibantu oleh masyarakat setiap hari senin, rabu dan sabtu adalah mengambil sampah organik ke tiap rumah untuk dikumpulkan dan diolah menjadi biodigester. Ada juga masyarakat yang menyimpan sampah organik dimasukan ke lubang biopori yang diletakkan di depan rumahnya. Selain kegiatan tersebut ada juga setiap hari kamis masyarakat membawa sampah anorganik dan buku tabungan. Sampah tersebut ditimbang ke bank sampah setelah itu oleh pengurus dicatat di buku tabungan. Tabungan tersebut dapat ditukarkan uang dengan persyaratan seminggu sebelum idul fitri.

\section{2.) Green Living (Ramah Lingkungan)}

Setiap hari jumat ada kegiatan jumsih (Jumat bersih) dimana kegiatan tersebut dilakukan oleh ibu-ibu dan para pengurus serta dengan bantuan masyarakat.

\section{3.) Edukasi}

Edukasi dan kampanye mengenai dampak kantong plastik, bahaya kantong plastik dan solusi dalam mengurangi penggunaan kantong plastik. Respon masyarakat sangat baik dan antusias saat pemberian edukasi tersebut. Biasanya dilakukan kegiatan ini di hari minggu. Tidak hanya edukasi tentang dampak kantong plastik tetapi memberikan arahan agar plastik dapat digunakan menjadi bermanfaat. Setiap para wisatawan yang datang ke Kampung Wisata Cibunut dilarang membawa botol plastik ke dalam agar menghindari sampah plastik.

\section{4.) Pariwisata}

Kampung Wisata Cibunut tidak hanya dilingkup pengolahan sampah tetapi menjadi sektor pariwisata. Hal ini menjadi DTW unggulan di Kota Bandung karena yang ditawarkan di Kampung Wisata Cibunut ada faktor edukasi. Edukasi yang ditawarkan disini bagaimana mengolah sampah organik menjadi biogas. Wisatawan pun ikut terjun langsung dalam mengolah sampah tersebut. Selain edukasi tersebut Kampung Wisata Cibunut menyuguhkan tembok-tembok yang instagramble untuk menjadi spot selfie. 


\section{5.) Kreatifitas}

Masyarakat membuat kerajinan dari sampah anorganik yang dibuat dengan model yang unik dan bermanfaat untuk digunakan. Seperti alas meja yang terbuat dari plastik bekas bungkus kopi, ada juga yang membuat baju dari sampah anorganik dan ada yang membuat gantungan lampu menggunakan botol plastik bekas.

6.) Kesehatan

Kegiatan yang dilakukan akan menjadi bersih, nyaman sehingga kesehatan pun akan terjaga untuk masyarakatnya sendiri. Setiap 1 bulan sekali ada pemeriksaan kesehatan untuk masyarakat yang dikelola oleh ibu PKK yang dilaksanakan di balai RW 07. Kegiatan tersebut biasanya penimbangan balita, pemeriksaan lansia agar kesehatan masyarakat tersebut terkontrol dengan baik.

\section{Faktor-faktor kemenarikan dalam pemberdayaan masyarakat di Kampung Wisata Cibunut Kota Bandung}

a. Atraksi

Kampung Wisata Cibunut memiliki konsep yang unik, Kampung Wisata Cibunut menerapkan konsep "zero waste" dan kampung selfie. Wisatawan dapat merasakan suasana yang berbeda dari kampung-kampung yang lainnya. Selain dapat merasakan suasana yang berbeda, pengunjung juga dapat langsung melihat pengelolaan sampah organik menjadi biogester.

Macam aktivitas di Kampung Wisata Cibunut, paling banyak diminati dan dilakukan oleh pengunjung yang datang ke Kampung Wisata Cibunut pada hari-hari di akhir pekan maupun hari libur nasional bersama teman, dan keluarga, antara lain wisatawan datang umumnya untuk mengetahui cara pengolahan limbah organik menjadi biogester yang hasilnya dapat dimanfaatkan oleh masyarakat sekitar untuk kebutuhan sehari-hari.

Pengunjung tidak hanya melihat cara mengolah sampah tetapi dapat mengikuti proses pembuatan dari mulai memilah sampah hingga siap digunakan. Pengunjung pun 
dapat selfie di tembok-tembok mural berbeda tema setiap wilayah yang membuat ciri khas berbeda antara Kampung Wisata Cibunut dengan kampung lainnya. Hal ini menunjukan bahwa kemenarikan atraksi dengan dimensi kemenarikan aktivitas wisata di Kampung Wisata Cibunut cukup menarik perhatian pengunjung dengan pengetahuan yang didapat menjadi daya tarik tersendiri bagi pengunjung untuk datang ke Kampung Wisata Cibunut.

b. Amenitas

Kampung Wisata Cibunut telah dilengkapi dengan beberapa fasilitas wisata, namun hingga saat ini masih dalam jumlah dan kondisi yang terbatas. Fasilitas tersebut antara lain :

1) Lahan Parkir

Kampung Wisata Cibunut memiliki satu pintu masuk melalui gang Cibunut. Lokasi Kampung Wisata Cibunut ini memiliki 2 lahan parkir. Lahan parkir pertama tidak jauh dari jalan raya sehingga pengunjung yang membawa kendaraan pribadi roda empat disediakan tempat parkir di lahan pertokoan. Sedangkan satu lahan parkir disediakan untuk pengunjung yang membawa kendaraan roda dua di lapangan RT 09. Keamanannya pun terjaga karena terdapat pos keamanan berikut dengan petugasnya.

2) Toilet

Toilet merupakan fasilitas yang harus terdapat pada setiap daya tarik wisata. Kampung Wisata Cibunut mempunyai toilet yang tersedia di beberapa rumah masyarakat.

3) Sarana Informasi Wisata

Sarana informasi merupakan fasilitas yang harus terdapat pada setiap daya tarik wisata. Kampung Wisata Cibunut memiliki sarana Informasi yang bertempat di balai RW 07. Petugas yang menjaga sarana informasi ini didominasi oleh karang taruna, yang selalu ada dengan cara bergantian waktu (shift).

4) Shelter

Shelter yang disediakan oleh Kampung Wisata Cibunut relatif kecil karena hanya dapat menampung sekitar 50 pengunjung yang ingin melihat pengolahan Biogas.

5) Tempat Ibadah

Kampung Wisata Cibunut menyediakan 2 (dua) masjid yang tersebar di beberapa tempat, 
seperti masjid yang berada di dekat shelter dan di dekat pemukiman masyarakat.

c. Aksesibilitas

Kemudahan akses informasi menuju lokasi juga kondisi jalan menuju Kampung Wisata Cibunut sangat mudah dilalui karena melewati jalan provinsi. Papan petunjuk arah tidak ada yang menunjukkan Kampung Wisata Cibunut dan hanya terdapat di pintu masuk daya tarik wisata sedikit membuat pengunjung kesulitan menemukan informasi.

Menuju Kampung Wisata Cibunut, terdapat angkutan umum yang melewati atau menuju ke tempat ini. Pengunjung dapat menggunakan ojek online sebagai kendaraan menuju ke Kampung Wisata Cibunut. Untuk yang menggunakan kendaraan pribadi mudah akses lokasi karena di tengah kota dengan aplikasi google maps.

Tingkat keamanan jalur menuju lokasi dapat dinilai cukup baik, hal tersebut didasari atas keterangan narasumber dan hasil observasi bahwa keadaan tingkat kriminal dan kecelakaan tergolong rendah, lampu penerangan yang sudah cukup selama perjalanan ke arah Kampung Wisata Cibunut sangat baik.

Selain dari berbagai hal yang telah diuraikan di atas, yang berkaitan dengan aspek aksesibilitas lainnya adalah pusat perbelanjaan yang sangat mudah dijangkau oleh wisatawan apabila telah selesai mengunjungi Kampung Wisata Cibunut, karena dekatnya Kampung Wisata Cibunut dengan pusat kota.

d. Ancillary

1) Kelestarian Alam dan Lingkungan

Kampung Wisata Cibunut pada awalnya sebagai wilayah yang kumuh dan padat penduduk. Namun, kini Kampung Cibunut telah berubah menjadi kampung kreatif yang ramah lingkungan. Berdasarkan hasil wawancara dengan pihak pengelola pemanfaataan sampah organik maupun non organik dapat mengubah kebiasaan masyarakat dalam selektif memilih sampah yang dapat bermanfaat bagi masyarakat itu sendiri.

2) Kualitas Pelayanan

Kampung Wisata Cibunut memiliki 12 pengelola yang jumlah pengelola tersebut merupakan penduduk asli Cibunut. Partisipasi kaum muda karang taruna tersebut sangat 
positif karena membantu pihak pengelola dalam mempromosikan dan dari kreatifitas juga berkontribusi langsung terhadap Kampung Wisata Cibunut.

Hasil analisis faktor-faktor kemenarikan dalam pemberdayaan masyarakat di Kampung Wisata Cibunut, adalah:

1. Persepsi wisatawan mengenai existing Penilaian wisatawan secara keseluruhan berada di kategori baik. Pada sarana prasarana rata-rata 109,4 terletak di posisi baik, namun persediaan parkir yang perlu ditata oleh pihak pengelola, karena sebagian wisatawan mengeluh terhadap persediaan tempat parkir terutama pengguna kendaraan roda empat atau rombongan yang menggunakan bis pariwisata. Pada kualitas lingkungan rata-rata 130,8 terletak pada posisi sangat baik, terutama dalam kondisi tempat wisata. Dari segi pengamanan dan partisipasi masyarakat perlu ditingkatkan untuk kenyamanan wisatawan yang berkunjung. Belanja pariwisata rata-rata 110 pada kategori murah. Untuk penginapan karena relatif mahal, wisatawan tidak ada keinginan untuk long stay tapi hanya memilih full day. Sumber daya alam rata-rata berada di penilaian 140 terletak sangat baik karena masyarakat sadar dalam melestarikan lingkungan juga flora.

2. Persepsi wisatawan mengenai faktor-faktor kemenarikan Atraksi memiliki jumlah rata-rata 116,8 terletak pada posisi baik dalam pengelolaan. Edukasi yang diberikan pada wisatawan oleh pihak pengelola dalam menjelaskan pengolahan sampah sudah baik. Amenitas rata-rata 116,6 terletak diposisi baik, kekurangannya hanya wisatawan tidak sadar terhadap lingkungan sehingga menimbulkan sampah. Aksesibilitas mempunyai jumlah rata-rata 118,5 terletak baik, karena mudah dilalui angkutan umum dan penggunaan aplikasi google maps. Ancillary mempunyai jumlah rata-rata 114,2 terletak baik, tetapi tidak ada paket wisata kepada wisatawan untuk mengikuti kegiatan di Kampung Wisata Cibunut Kota Bandung.

\section{KESIMPULAN DAN SARAN}

Melalui penelitian mengenai analisis faktor-faktor kemenarikan dalam pemberdayaan masyarakat di Kampung Wisata Cibunut Kota Bandung, maka 
disimpulkan:

1. Cibunut memiliki kondisi existing yang menarik, masyarakat giat mempromosikan melalui media sosial dan mengikuti pameran wisata.

2. Pengelola melakukan penataan tempat parkir dan toko cinderamata, juga masyarakat sekarang sudah mulai membuat paket wisata yang dapat ditawarkan pada wisatawan, sehingga partisipasi ini dapat mendukung pemberdayaan masyarakat

\section{DAFTAR PUSTAKA}

Dewi, M. H. U. (2013). Pengembangan desa isata berbasis partisipasi masyarakat lokal di Desa Wisata Jatiluwih Tabanan, Bali. Jurnal Kawistara, 3(2). /*doi:http://dx.doi.org/10.22146/kawistara.3976*/doi:https://doi.org/10.22146/kawi stara.3976

Fitriana, R., \& Sarmadi, K. A. (2019). PENGARUH DAYA TARIK TAMAN POTRET TERHADAP KEPUASAN WISATAWAN. IKRA-ITH HUMANIORA: Jurnal Sosial dan Humaniora, 3(3), 155-162.

Hadiwijoyo, Suryo Sakti. (2012). Perencanaan Pariwisata Perdesaan Berbasis Masyarakat. Yogjakarta: Graha Ilmu

Kusmayadi, \& Endar, S. (2000). Metodologi Penelitian dalam Bidang Kepariwisataan. Jakarta: Gramedia Pustaka Utama

Marpaung, H. (2002). Pengantar Pariwisata. Bandung: Alfabeta

Marpaung, H., \& Herman, B. (2002). Pengantar Pariwisata. Bandung: Alfabeta

Ocktaviany, T. (2019). Sektor utama ekonomi nasional pariwisata akan menjadi penghasil devisa terbesar. Retrieved March 19, 2020, from News website: www.inews.id/travel/destinasi/sektor -utama-ekonomi-nasional-pariwisata-akan$\% 0$ Amenjadi-penghasil-devisa-terbesar

Risman, A., Wibhawa, B., \& Fedryansyah, M. (2016). KONTRIBUSI PARIWISATA TERHADAP 


\section{JURNAL EKBIS \\ ANALISIS, PREDIKSI, DAN INFORMASI} Csînta

INDONESIA. Prosiding Penelitian Dan Pengabdian Kepada Masyarakat. https://doi.org/10.24198/jppm.v3i1.13622

Republik Indonesia. (2009). Undang-Undang No. 10 Tahun 2009 Tentang Kepariwisataan

Sedarmayanti, Gumelar \& Lia. (2018). Pembangunan dan Pengembangan Pariwisata.

Bandung: Refika

Sedarmayanti, \& Hidayat, Syarifudin. (2002). Metodologi Penelitian. Bandung: Mandar Maju

Sugiyono. (2007). Metode Penelitian Kuantitatif Kualitatif dan R\&D. Bandung: Alfabeta

Sugiyono. (2011). Metode Penelitian Kombinasi. Bandung: Alfabeta

Suwantoro. (2004). Dasar-Dasar Pariwisata. Yogyakarta: Andi

Suwantoro. (2004). Daya Tarik Wisata. Yogyakarta: Andi

Trisnawati, A. E., Wahyono, H., \& Wardoyo, C. (2018). Pengembangan desa wisata dan pemberdayaan masyarakat berbasis potensi lokal. Jurnal Pendidikan: Teori, Penelitian, dan Pengembangan, 3(1), 29-33.

DOI: http://dx.doi.org/10.17977/jptpp.v3i1.10356

Umar, Husein. (2003). Metodologi Penelitian: Aplikasi dalam Pemasaran. Jakarta: Gramedia Pustaka Utama

Vengesayi, S., Mavondo, F. T., \& Reisinger, Y. (2009). Tourism destination attractiveness: Attractions, facilities, and people as predictors. Tourism Analysis, 14(5), 621-636. DOI: 10.3727/108354209X12597959359211.

Wardiyanta. (2006). Metode Penelitian Pariwisata. Yogyakarta: Andi

Wearing, S., \& McDonald, M. (2002). The development of community-based tourism: Re-thinking the relationship between tour operators and development agents as intermediaries in rural and isolated area communities. Journal of sustainable tourism, 10(3), 191-206

http://www.ayobandung.com/read/201801/13/27423/susur-bandung-mengintipwarna-warnidi-kampung-cibunut 